\title{
ASPHALT EXTRACTION TEST INVESTIGATION: POST AUDIT URGENCY AND THE FOLLOW UPS (CASE STUDY: ROAD SEGMENT MAINTENANCE Ir. SOEKARNO Rd-BATU)
}

\author{
Riandono Pramaputro ${ }^{1}$ \\ ${ }^{1}$ Young Expert Auditor, Inspectorate of East Java Province, Ngagel Jaya Tengah 102 \\ Surabaya, Indonesia \\ E-mail: riandono@hotmail.com
}

\begin{abstract}
In the most common opinions, the asphalt content test cannot be carried out during the post audit. But there are complaints about the poor quality of hotmix asphalt works in public sector projects from road users. In these cases, auditors must maintain reputation of the Government to accommodate trust in the development that has been done, by carrying out the function of monitoring and evaluating, including in the evaluating of road maintenance work. From visual observations, the the most conditions of routine maintenance work (on the study object) are not good as expected. Also, the test results of the asphalt content in the mixture (extraction) have proven that the quality does not meet the required technical specifications, in where the density value and the mixed asphalt content is $15.24 \%$ lower than the allowable tolerance. Under these conditions, auditors can assume that the similarity range of asphalt concrete ( $A C$ $W C$ ) quality is still too far from the required specifications. Complaints about the poor quality of hotmix asphalt works must be accommodated by auditors to maintain the image and reputation of the Government in the trust of Regional Development.
\end{abstract}

Keywords: Road maintenance; asphalt content in mixture; extraction test; audit; evaluating.

\section{Introduction}

Every construction work is certainly expected to produce adequate construction buildings and meet the requirements set. Management as the operator of construction work is obliged to realize the success of project implementation, by fulfilling the provisions for its implementation. the fact that road management agencies in most of the developing countries have limited resources, staff and data to plan the interventions carried out on road networks [1].

Quality testing of the work is a compulsory control, the same applies to road maintenance works. Also in other research that research the quality testing by interviewing project management practitioners [2]. One of quality testing is asphalt testing. The laboratory tests are also to find the amount of asphalt content, the proportion and quality of the aggregate gradation, and the characteristics of the asphalt mixture (density, VIM, VMA, VFB, stability, flow, MQ) [3]. The asphalt-concrete mixture was tested using the Marshall Test method [4].

From many management opinions (Commitment-Making Officers, Contractors, and Consultants), the asphalt content test cannot be carried out during the post audit, considering that apart from the asphalt aging factor, this can only be done when the AC-WC spread process is carried out, by taking loose samples behind the finisher or those in the Asphalt Mixing Plant (AMP).

Auditors as Government Internal Supervisory Apparatus in Indonesia must maintain the image and reputation of the Government to accommodate trust in the development that has been done, by carrying out the function of monitoring and evaluating, including in the evaluating of road maintenance work. So there are several problems that occur there are the role position of auditors as the Government Internal Supervisory Apparatus in responding to public complaints, especially to 
evaluate the performance of services provided by the Government; level of importance for testing the asphalt content in mixture (extraction test) by the auditor during the post audit; and how to follow up on the results of the asphalt level test on the results of the post audit. This research purposes are providing confidence that the role of auditors as the Government Internal Supervisory Apparatus in guarding the accountability of construction projects is very important to maintain the performance of services provided by the Government; providing assurance to auditors, in general, not to hesitate to test asphalt content during the post audit as part of quality control of work results; and providing confidence that the contribution of the audit results by the auditors can be useful for the public, especially to accommodate the safety of road users.

\section{Material and Method}

\subsection{Theoretical}

1. The differences in motivation and information asymmetry cause concern about the reliability of the information provided, which has an impact on the level of trust of the principal (service owner) in their agent (service provider). Monitoring and evaluation mechanisms for agent performance include auditing [5];

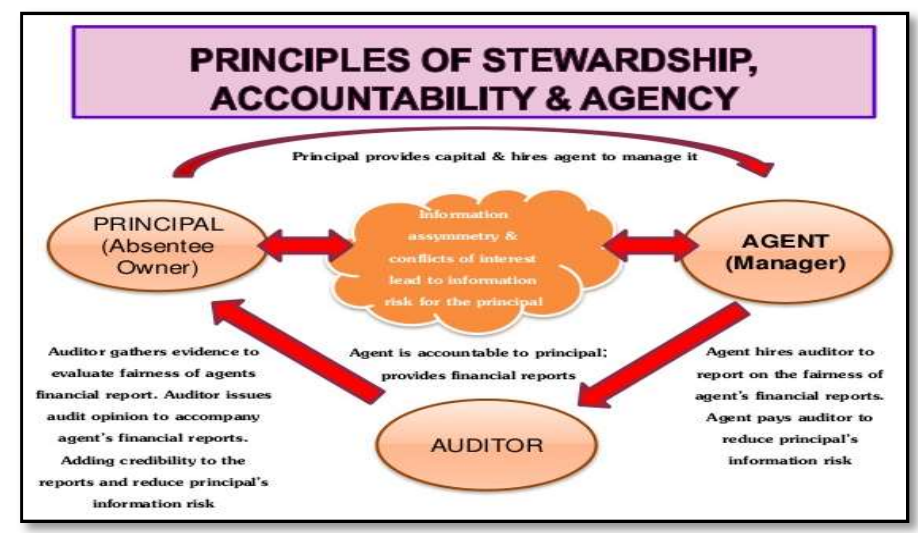

Figure 1. Principles of Stewardship, Accountability, and Agency Cycle Theory

2. Supervision of the infrastructure development of Regional Government is the effort, action and activity aimed at ensuring that the administration of the Regional Government runs efficiently and effectively in accordance with the provisions of constitutions and regulations. The Government Internal Supervisory Apparatus is the inspectorate general of the ministry, the supervisory unit for non-ministerial government agencies, the provincial inspectorate, and the district/city inspectorate like written in Indonesian Government Regulation, Number 12 of 2017, and also implementation of the government internal control system and the use of information technology in improving the quality of reports on local-owned asset reports in Government [6];

3. The implementation of internal audits within Government agencies is carried out by officials who have the task of carrying out supervision and who have met the expertise competency requirements as auditors as stipulated by the Agency for Functional Positions as written in Article 51, Indonesian Government Regulation, Number 60 of 2008. But any research found that there is no support for the audit professionalism on internal audit effectiveness [7];

4. Auditor's professional skepticism is the auditor's attitude in conducting audit engagements in which this attitude includes a mind that always questions and performs critical evaluation of audit evidence. Since audit evidence is collected and assessed during the audit process, professional skepticism must be used during the process (IAI. 2001, SA Section 230; AICPA, 2002, AU 230);

5. Professional skepticism as an auditor's personality includes prudence, vigilance, not just believing, critical assessment, questioning the validity of evidence, the reliability of 
evidence, being aware of contradictory evidence, authenticity of evidence, engineering evidence, suspecting suspicious matters, assessing results non-generalized observations, conduct careful evaluations and make conservative conclusions. Auditor's professional skepticism will lead him to ask every signal that indicates the possibility of occurrence [8].

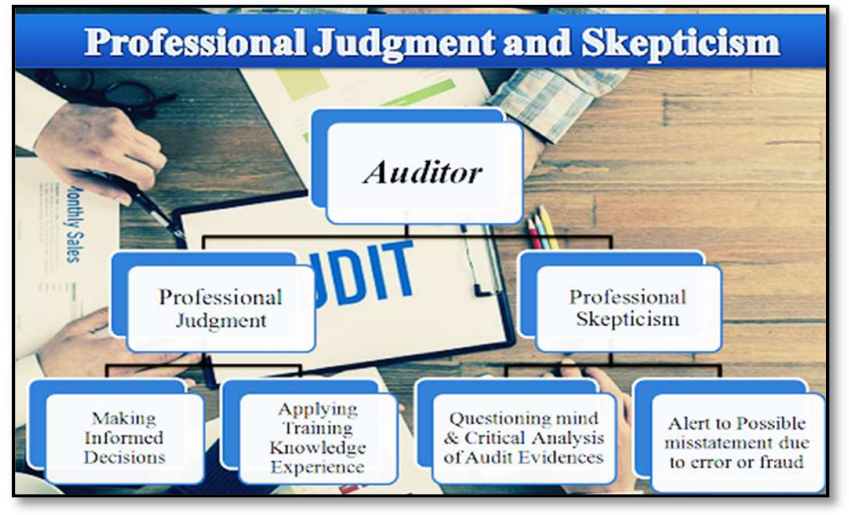

Figure 2. Schemes of Auditor's Professional Judgment and Skepticism

6. There are 3 (three) main emphases on the focus of monitoring the administration of Regional Government. First, the Government Internal Supervisory Apparatus becomes a clearance by being in a key position in determining whether a public complaint has criminal or administrative indications and coordinates with Law Enforcement Officials in handling public complaints. Second, the Government Internal Supervisory Apparatus must truly be able to function as an early warning system oriented towards preventive actions so as to ensure that programs and activities can be carried out with good, measurable accountability and no waste of budget and play an active role in providing consulting services. Third, The Government Internal Supervisory Apparatus must be able to become a trusted advisor who previously served as an assurance provider. The Government Internal Supervisory Apparatus as the third line of defense is expected to be able to actively advise stakeholders and increase value in the achievement of regional development goals and services to the public. Suggestions by the Government Internal Supervisory Apparatus not only in the technical and short-term realms, but also in the strategic realm, in terms of regional development planning and development policies. Also successful implementation of risk-based audit is determined by several factors, such as the role of internal auditors, commitment of the top management, and professional development [9].

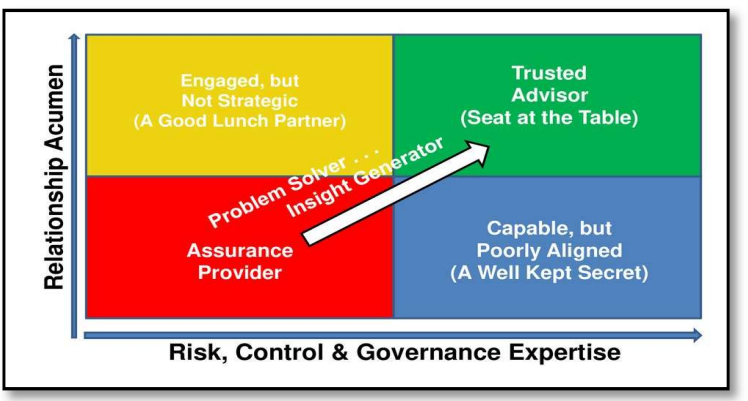

Figure 3. Diagram of Developing the Role of Auditor as The Government Internal Supervisory Apparatus, as a Problem Solver

7. One type of test in determining the quality requirements of asphalt is the penetration of asphalt which is the rheological characteristic of asphalt, namely the hardness of asphalt. The results of this test can then be used in terms of quality control of asphalt or tar for road construction, improvement or maintenance purposes. This penetration test is very much 
influenced by the total load weight, angle size and needle surface smoothness, temperature and time (RSNI 06-2456-1991);

8. The mechanical properties of the asphalt mixture are derived from the friction and cohesion of the constituent ingredients. The performance of the asphalt mixture is greatly influenced by the properties of the aggregate and the asphalt as well as the properties of the solid mixture that has been formed from the two materials. Sampling and testing are two very important things in the quality control function [10].

\subsection{Documents/Regulations Related}

1. Quality test for hot mix asphalt (including AC-WC) if during the AMP sampling test is in production and/or asphalt laying is running, loose samples are taken behind the finisher or at AMP for testing the asphalt content in the laboratory (extraction). The sample testing method for asphalt density is carried out based on SNI (Indonesian National Standart) 036757-2002 and for testing asphalt content based on SNI 03-6894-2002;

2. The provisions contained in the Contract documents of Roads Routine Maintenance for Ir. Soekarno Rd - Batu (Link. 192.16K) Cs, some of them:

- Contract agreement articles;

- General Conditions and Special Conditions of Contract;

- Technical specifications;

- Job Mix Formula (JMF);

- Technical Plan Drawing;

3. General Specifications of Highways Year 2018 for Road and Bridge Construction Works (Form Letter of the Directorate General of Highways Number 02/SE/Db/2018) Division 6 concerning Asphalt Pavement, issued by the Directorate General of Highways of the Ministry of Public Works and Housing;

4. General Specifications of the Public Works Office of Highways of East Java Province 2018 Division 6 concerning Asphalt Pavement, issued by the Public Works Office of Highways of East Java Province;

5. Indonesia Presidential Regulation Number 16 of 2018 concerning Government Procurement of Goods/Services:

6. Regulation of the Agency of Procurement Policy of Indonesian Government Number 9 of 2018 concerning Guidelines for the Implementation of Government Procurement of Goods/Services through Providers, related to contract control: Chapter VII Number 7.10;

7. Minister of Public Works Regulation Number 13/PRT/M/2011 concerning Procedures for Road Maintenance and Surveillance;

8. Minister of Public Works Regulation Number 07/PRT/M/2019 concerning Standards and Guidelines for the Procurement of Construction Services through Providers;

9. Constitution of the Republic of Indonesia Number 22 Year 2009 concerning Road Traffic and Transportation;

10. East Java Governor Regulation Number 63 of 2019 concerning Work Guidelines and Implementation of Regional Government Duties of East Java Province in 2020.

\subsection{Method}

The research was held on case that occurred in the routine maintenance work package for Ir. Soekarno Rd - Batu (Link. 192.16K) Cs, located in Malang and Batu City, East Java Province of Indonesia in 2020. The method is a mix method (combination) between quantitative and qualitative methods with a parallel-convergent approach, namely combining (convergence) between quantitative and qualitative data to produce a comprehensive analysis.

With this research method design the writer can collect 2 types of data at relatively the same time, then integrate the two data and the results of the research are confirmation of the two data collected.

The research method is also part of the audit carried out by the author, where the mechanism is by: 
a. Confirmation and clarification of authorized officers/officials, providers and through related documents;

b. Joint discussions and exchanging opinions with several auditors of the the Audit Board of Indonesia (Agency of East Java) on related topics;

c. Sampling test/physical check on the location;

d. Laboratory test.

As for the data regarding the projects to be investigated are as follows:

Construction Work:

Work Package Name : Road Routine Maintenance for Ir. Soekarno Rd - Batu (Link. 192,16K) Cs.

Type of Works $\quad$ : Patching of the road at certain spots

Job Location : : Malang and Batu City, East Java, Indonesia

Execution Time $\quad$ : 210 calendar days (16 April to 17 October 2019)

Maintenance Period : 90 calendar days (until 16 January 2020)

Physical Progress $\quad: \quad 100 \%$ (according to the Supervision Result Report)

\section{Result and Discussion}

During the process, confirmation and clarification of the road maintenance project management, namely the authorized officers/officials and service providers (Contractors and Supervision Consultants) are carried out. Likewise, the analysis will be carried out on the sampling results at the location and also the laboratory test results, before being used as a discussion in this study.

\subsection{Confirmation and Clarification}

The following information can be gathered from the confirmation and clarification results:

a) Head of Technical Implementation Unit Office of Road and Bridge Maintenance in Malang, as the Proxy of Budget User:

- expressing his dissatisfaction with the work of the Provider (Contractor) because the physical quality of the patching is not good, many roads are potholed and damaged;

- his dissatisfaction was also due to reports of public complaints who complained about the results of road maintenance (patching asphalt hotmix AC-WC) with lots of holes and damage, and there were even minor accidents of motorized two-wheeled road users;

- Due to the slow response from the Commitment-Making Officer to immediately handle this matter, he unilaterally took several samples of the AC-WC layer by means of a core drill test and tested them in the laboratory to determine their quality through the extraction test. This was done due to disappointment with the Commitment-Making Officer which still maintained the inconclusive results of the asphalt extraction test by the Provider (Contractor);

- by knowing the results of the asphalt content test in the mixture (extraction) which indicated that the quality of the asphalt did not meet the requirements, Proxy of Budget User took the initiative to report this to the Head of the Public Works Department of Highways and asked the Inspectorate of East Java Province as Government Internal Supervisory Apparatus to conduct an inspection;

b) Commitment-Making Officer:

- states that the asphalt extraction test carried out by the Contractor has been carried out during the implementation, namely loose samples taken behind the finisher during the laying out and samples taken from AMP during the work implementation period;

- stated that at the time of the Provisional Hand Over (PHO) she did not participate in overseeing the work location testing, but delegated it to the PHO Team and the result was that the patching work by the Contractor had been completed and was $100 \%$ acceptable;

- regarding the results of the asphalt extraction test conducted by Proxy of Budget User, she admits didn't know anything and didn't take responsibility for the results because according to her the test can only be done during the process of carrying out the work, not after the work is finished, on the grounds that the asphalt has gone through a period 
of formation and aging (aging), and there is no technical basis to use the extraction test results as justification;

c) The Contractor:

- declare that they have carried out the duties and responsibilities in accordance with the agreed contract, including the technical requirements of the $\mathrm{AC}-\mathrm{WC}$ specifications carried out in the work location;

- because they felt they had carried out a quality test, namely the asphalt level extraction test in the laboratory during the implementation of the AC-WC laying with results that met the requirements, they questioned what else should be improved on the AC-WC layer they were working on;

d) The Supervision Consultant:

- did not expect that the condition of the maintenance work in the form of AC-WC coating by the Contractor was not good, even though during the quality testing (extraction of asphalt content) the performance of the work showed that the results were in accordance with the specifications required in the Contract and the implementation of the work in the work location was sufficient in accordance with the method that is enforced.

\subsection{Documents Related Checking}

As for the results of documents checking, there are known that:

a. Referring to the provisions/clauses of the Contract, the reference standards used are:

- The value of the AC-WC mixture asphalt content: $6.00 \%$, tolerance: $\pm 3.00 \%$;

- AC-WC mixture density value: $2.303 \mathrm{~g} / \mathrm{cm} 3$, tolerance: $98.00 \%$.

b. In the Contract clauses on the Special Conditions of Contract, related to the repair of quality defects in Number 75.4 Letter W, there are explained that:

1) The provider must guarantee all the results of the work he has performed, by replacing or repairing the loss or damage as referred to in the General Conditions of Contract;

2) Delay in handling of the response time as stipulated in the Special Conditions of Contract, Road Performance Indicators, and Response Time Limits, must be interpreted as negligence/default from the Provider so that the handling can be taken over by Commitment-Making Officer or other parties determined by Commitment-Making Officer. All handling costs must be borne by the Provider;

3) If the Provider is not willing to pay such fees, the reimbursement is made by disbursing the Maintenance Guarantee by terminating the Contract and the relevant Provider is included in the Black List;

4) Referring to General Conditions of Contract, the Provider must allow CommitmentMaking Officer or other parties assigned to either carry out routine maintenance or repairs for damage other than those referred to in General Conditions of Contract. The provision of the Provider as above does not relieve the Provider from the responsibility of the guarantee as stated in Point 1.

c. In the Special Conditions of Contract clauses, in relation to matters relating to public dissatisfaction/complaints, they state that:

- Any complaints from road users/public that are submitted must be immediately verified at location by the Provider to be followed up according to the road performance indicators required in the Contract and reported to the Commitment-Making Officer or the Technical Board of Directors. For this purpose, the Provider must prepare an operator or a person in charge of recording regularly for each complaint, and further action must be submitted to the Commitment-Making Officer and the Technical Board of Directors within 7 days after the Provider receives the complaint;

- Against all complaints, complaints and reports from public/journalists/NGOs for the implementation of work during the Contract period whose damage is due to negligence in implementation, the settlement is the responsibility of the Provider to complete it.

d. In the Special Conditions of Contract clause, related to inspection and testing (which the auditor can also do during the post audit), it is explained that: 
Arrangements regarding the inspection, testing, investigation, research or evaluation of the quality or quantity of work by any party against this Contract shall be subject to the requirements, methodology, measurement limits and tolerances contained in the General Specifications, Special Specifications and Plan Drawings.

e. In the Special Conditions of Contract clauses, regarding the handling/improvement of road pavement conditions within the response time limit, the details are described and explained in the Table of Road Performance Indicators for Flexible/Rigid Pavement as follows:

Table 1. Road Performance Indicators for Flexible/Rigid Pavement

\begin{tabular}{|c|c|c|}
\hline No. & $\begin{array}{l}\text { Road Performance Indicators } \\
\text { (Pavement Conditions) }\end{array}$ & $\begin{array}{l}\text { Handling Response Time } \\
\text { (Must Be) }\end{array}$ \\
\hline $\mathrm{a}$ & $\begin{array}{l}\text { Hole : } \\
\text { There shall be no pits with a diameter of more than } 10 \mathrm{~cm} \text { and a depth of } \\
\text { more than } 4 \mathrm{~cm} \text { in the road section. }\end{array}$ & $\begin{array}{l}\text { finished repairing within a } \\
\text { maximum of } 7 \text { days }\end{array}$ \\
\hline $\mathrm{b}$ & $\begin{array}{l}\text { Cracks: } \\
\text { i) There shall be no cracks wider than } 3 \mathrm{~mm} \text { for asphalt / flexible } \\
\text { surfaces. } \\
\text { ii) There shall be no cracks wider than } 5 \mathrm{~mm} \text { for rigid pavement surfaces. } \\
\text { iii) There shall be no greater crack area } 10 \% \text { for every } 100 \mathrm{~m} \text { of road } \\
\text { length. }\end{array}$ & $\begin{array}{l}\text { closed within a maximum of } 14 \\
\text { days }\end{array}$ \\
\hline $\mathrm{c}$ & $\begin{array}{l}\text { Subsidence: } \\
\text { There should not be any subsidence of more than } 3 \mathrm{~cm} \text { with a surface } \\
\text { area of more than } 5 \% \text { subsidence every } 100 \text { meters of the road. }\end{array}$ & $\begin{array}{l}\text { closed within a maximum of } 7 \\
\text { days }\end{array}$ \\
\hline $\mathrm{d}$ & $\begin{array}{l}\text { Grain Release: } \\
\text { There shall be no part of the road surface that is subject to grain release. }\end{array}$ & finish closed within 14 days \\
\hline $\mathrm{e}$ & $\begin{array}{l}\text { Faulting on rigid pavement } \\
\text { There should not be any parts of the road that experience faults } \\
\text { (faulting). }\end{array}$ & completed within 42 days \\
\hline $\mathrm{f}$ & $\begin{array}{l}\text { Pumping on rigid pavement } \\
\text { There should not be any parts of the road that experience pumping. }\end{array}$ & completed within 42 days \\
\hline $\mathrm{g}$ & $\begin{array}{l}\text { Rocking on rigid pavement } \\
\text { No rocking on any part of the road. }\end{array}$ & completed within 42 days \\
\hline $\mathrm{h}$ & $\begin{array}{l}\text { Joint sealant on rigid pavement } \\
\text { In good condition, it should not be damaged or lost in any slab joints. }\end{array}$ & repaired within 28 days \\
\hline
\end{tabular}

f. In the General Specifications of the Public Works Office of Highways of East Java Province, Division 6 on Asphalt Pavement, the discussion on Taking Asphalt Mixed Test Objects explains that:

- the core test object (which is taken by a drilling machine to extract the core test object) may not be used for extraction testing;

- the extraction test shall be carried out using a loose asphalt mixture specimen which is taken behind a spreader;

- asphalt mixture quality control testing (extraction) must meet the criteria and steps set out in these Specifications;

g. The publication of the Back-Up Quality document that attaches the test results of the asphalt content in the mixture (extraction) shows the test results of the AC-WC material that meet the specifications requirements. However, the identity of the laboratory that is used is not clear (there is no laboratory name, address, and accreditation);

h. The results of the asphalt level extraction test conducted by the Proxy of Budget User unilaterally as a form of dissatisfaction with the performance of the Provider (Contractor) showed that the AC-WC quality number (asphalt content and density) did not meet the required specifications.

\subsection{Inspection Results and Analysis}

Physical observation and inspection by tools of core drill tests on the work location involving several parties, that are Proxy of Budget User, Commitment-Making Officer, and the Providers (Contractor and Supervision Consultants), is carried out on road sections resulting from 
patching. Likewise, laboratory testing (extraction) is also carried out to obtain the asphalt content value from the physical inspection.

Table 2. Core Drill Test Results

\begin{tabular}{|c|c|c|c|c|}
\hline No. & $\begin{array}{c}\text { Station } \\
\text { (Right/Left/CL) }\end{array}$ & $\begin{array}{c}\text { Asphalt } \\
\text { Types }\end{array}$ & Location / Section & Conditions \\
\hline 1 & PAT $0+300 \mathrm{~L}$ & AC-WC & Pattimura Rd, Batu City & - damage on the edges of the road \\
\hline 2 & PAT $0+450 \mathrm{~L}$ & AC-WC & Pattimura Rd, Batu City & - grained release \\
\hline 3 & MHT $1+125$ L & AC-WC & Moh. Hatta Rd, Batu City & - trash in the asphalt pavement layer \\
\hline 4 & MT $0+450 \mathrm{~L}$ & AC-WC & Malang - Turen & - damage on the edges of the road \\
\hline 5 & $\mathrm{MT} 1+700 \mathrm{R}$ & AC-WC & Malang - Turen & $\begin{array}{l}\text { - } \text { grained release } \\
\text { - } \text { patching results are not good }\end{array}$ \\
\hline 6 & MT $7+550 \mathrm{R}$ & AC-WC & Malang - Turen & $\begin{array}{l}- \text { bleeding } \\
\text { - } \text { Hole dia. }=95 \mathrm{~cm}, \text { depth }=6 \mathrm{~cm}\end{array}$ \\
\hline 7 & MT $7+900 \mathrm{CL}$ & $\mathrm{AC}-\mathrm{WC}$ & Malang - Turen & $\begin{array}{l}\text { - The test object is destroyed when taken from } \\
\text { the core drill machine cone }\end{array}$ \\
\hline 8 & MT 7+950 CL & AC-WC & Malang - Turen & $\begin{array}{l}\text { - The test object is destroyed when taken from } \\
\text { the core drill machine cone }\end{array}$ \\
\hline 9 & $\begin{array}{l}\text { MT } 7+950 \text { (II) } \\
\text { CL }\end{array}$ & AC-WC & Malang - Turen & $\begin{array}{l}\text { - 2nd trial at the same point was successful (not } \\
\text { broken) }\end{array}$ \\
\hline 10 & MT $8+050 \mathrm{R}$ & AC-WC & Malang - Turen & - damage on the edges of the road \\
\hline 11 & KRL $4+900 \mathrm{Ki}$ & AC-WC & Karanglo, Malang City & - damage on the edges of the road \\
\hline 12 & KRL $5+750$ & AC-WC & Karanglo, Malang City & - damage on the edges of the road \\
\hline 13 & KRL $7+600 \mathrm{Ka}$ & AC-WC & Karanglo, Malang City & - damage on the edges of the road \\
\hline 14 & SOE $4+625 \mathrm{~L}$ & AC-WC & $\begin{array}{l}\text { Ir. Soekarno Rd, Batu } \\
\text { City }\end{array}$ & - damage on the edges of the road \\
\hline
\end{tabular}

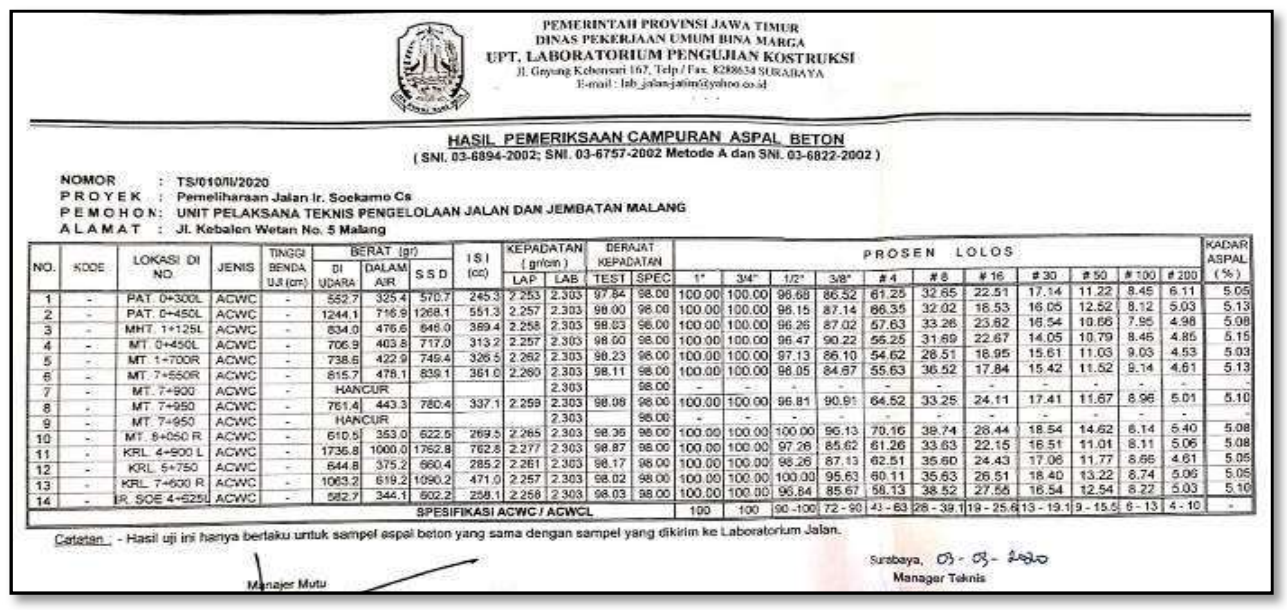

Figure 4. Copy of Documents on the Results of the Asphalt Content Test (Extraction)

The results of the analysis based on the inspection and physical observation on the work location and laboratory test results of asphalt content in the mixture (extraction) are:

- The 14 specimens from the core drill results, there were 2 specimens that were damaged (wrecked/broken), that are MT 7+900 and MT 7+950 (first tests). The other 12 specimens were then taken to the laboratory for the extraction and density tests;

- The 12 test specimens that have been tested for density, there is only 1 that is PAT $0+300 \mathrm{~L}$, where the value of the Degree of Density is $97.84 \%(<98.00 \%)$, where the value is $0.16 \%$ lower than the required tolerance; 
- The 12 test specimens that have been tested for extraction, all test objects have a value under the tolerance of $0.3 \%$ of the Job Mix Formula (JMF) where the lowest value is $5.03 \%$ and the highest is $5.15 \%$. If the minimum allowable value is: $6 \%-(6 \% \times 3 \%)=5.82 \%$, then the average value of asphalt content for the 12 specimens is $5.09 \%$ or $15.24 \%$ lower than the tolerance required;

\subsection{Discussion}

From the results of the analysis above, there are some important points to be discuss:

1. In general, from the results of visual observations when conducting core drill checks and tests, it can be seen that the conditions of the results of routine maintenance work in the form of AC-WC patching carried out by the Contractor are not as expected/not good, where the conditions seen in the work location include:

- Holes (potholes);

- Subsidence (grade depressions);

- Ravelling;

- Cracking;

2. Supported by observation notes on the work location conditions (refers to Point 1), it further strengthens the Auditors/team's justification for conducting laboratory tests on test objects taken from the results of the core drill, that is the extraction test to determine the content and density of asphalt in the mixture. This test is carried out by the auditor to determine the range of similarities/predictions to the quality of the AC-WC patching work which is spread over and applied during the implementation of the work, which can be used as a reference for opinion/judgment in inspection. The selected laboratory is an independent laboratory owned by the East Java Provincial Government which has been accredited nationally, that is the Technical Implementation Unit Office of Construction Testing Laboratory which is located in Surabaya City, East Java Province, Indonesia;

3. The test results of the asphalt content in the mixture (extraction) in the laboratory of the test objects taken from the results of the core drill test in the work location shown in Figure 4 have proven that the quality of work done by the Contractor does not meet the required technical specifications, in where the density value and especially the asphalt content in mixture is much lower than the allowable tolerance (according to the analysis results), which is $15.24 \%$ lower. Under these conditions, the auditors can assume that the similarity range of $\mathrm{AC}-\mathrm{WC}$ quality is still too far from the required specifications.

\section{Conclusions}

Based on the results of the analysis and discussion, it can be concluded that:

In terms of Project Management:

1. The Commitment-Making Officer as a manager in this project is slightly weak in controlling the implementation of work in the work location, which the work should be run according to the Contract (that has been agreed), among the weaknesses, there are:

a. Lack in monitoring the work of the Contractor;

b. Not being thorough in assessing the correctness of the information on the results of the asphalt content test (extraction) carried out by the Contractor, where the independence of the laboratory test is doubtful;

c. Lack of controlling the duties and responsibilities of the Supervision Consultant which is mandatory to supervise on the work location;

d. Lack in coordination with the Supervision Consultant, it is proven that the inaccuracies of the Physical Progress Report presented by the Supervision Consultant are not in accordance with the actual conditions;

2. The Contractor was negligent in carrying out his responsibilities to complete and produce work products in accordance with the Contract. Poor work results indicate unsatisfactory performance/not as expected, so that he should be held accountable for his negligence; 
3. The Supervision Consultant is negligent in its function and role to carefully supervise all implementation. They should have assisted the role of the Commitmet-Making Officer in terms of comprehensive supervision of every detail of the stages of construction work, including the implementation of quality control of work, so that any findings of quality mismatch should be their responsibility.

In terms of Post Audit Results:

1. The urgency of auditing by auditors with complaints from the public regarding services provided by the Government is a major consideration for auditors as trusted advisors to increase value in achieving regional development goals and services to the public;

2. The auditor has the right to test the object of the inspection and provide an assessment of the results of the test he carried out using professional judgment and audit steps that meet the requirements, including conducting a physical observation in the work location and testing the asphalt content in the mixture (extraction) during the post audit period

3. The results of the physical inspection in the work location conducted by the auditors, which are discussed in the results of the sampling test and the discussion in Sub-Chapter 3.3 indicate poor quality of patching work;

4. The test results of the asphalt content in the AC-WC mixture (extraction) by the auditor by appointing an independent and certified laboratory can be used as a reference for opinion/ judgment in the inspection, that is to determine the similarity/prediction range of the quality of the AC-WC patching work that is spread and applied. during the implementation of the work. The results show a range of density quality differences and in particular the content of mixed asphalt which is far from the tolerances allowed and from the required specifications;

5. Although the extraction test for asphalt content during the post audit (point 4) cannot be used as justification for the inspection due to aging factors and the conditions of asphalt formation, these results can provide direction for the auditor to provide an opinion on the results that are far from the permitted tolerance, especially by considering at poor physical results. The auditor's assumption regarding the condition is that it is probable that it could occur because:

- improper implementation method (stages not completely passed);

- improper use of tools (or poor condition of tools);

- the temperature of the mixed asphalt material (AC-WC) is not right (when spreading or compaction);

6. By combining the results of physical observation/inspection in the work location with laboratory tests, the auditor can integrate the two data and produce a comprehensive and confirmable analysis as part of the results of the audit;

7. The evaluated results of the Contractor's work clearly show the quality of work that does not meet the requirements and has a major risk impact on the safety of the road users. Coupled with the testing of the asphalt content (extraction) by the Contractor in a laboratory whose identity and independence were not clear, it resulted in a judgment from the auditor that the test could not be trusted;

8. The auditor can provide input recommendations on management as well as the sanctions imposed on the Contractor as a follow-up to the results of the audit.

The suggestions that can be given as a result of this research are:

In terms of Project Management:

The Head of Technical Implementation Unit Office of Road and Bridge Maintenance in Malang, as the Proxy of Budget User and as the management leader of this project can conduct a comprehensive evaluation of the implementation of the work, and instruct the Commitment-Making Officer to:

a. In the future, it is obligatory to exercise full control over every work in the work location and must refer to the applicable standard provisions and the clauses required in the Contract;

b. Be more careful in assessing the accuracy of the information presented by the Contractor;

c. Be more careful in monitoring the Physical Progress Report presented by the Supervision Consultant; 
d. Warn/give a written warning to the Contractor for their negligence in carrying out their duties and responsibilities which results in work products that do not comply with the required specifications and result in poor quality of work;

e. Requesting the Contractor to dismantle and repair the results of their work at all points/areas of the AC-WC layer that have been inspected/tested by the auditor as well as at other AC-WC points/areas that show similar visual conditions. This is a consequence for the Contractor to guarantee all the results of the work they have performed, by carrying out replacement or repair of loss or damage as intended General and Special Conditions of Contract;

f. Warn/give a written warning to the Supervision Consultant who is negligent in the supervision activities in the work location, especially in controlling the quality of work;

In terms of Post Audit Results:

1. The auditors must remain convinced that the role of the Government's Internal Supervisory Apparatus in guarding the accountability of national development is very important to maintain the performance of services provided by the Government;

2. Auditors should not hesitate to held the asphalt content test in the mixture (extraction) at the time of the post audit, as long as the mechanism and judgment are taken through professional judgment and based on applicable provisions and standards;

3. The auditor must remain convinced that the contribution of the audit results is basically to ensure the implementation of an effective and efficient Regional Government in accordance with the provisions of the prevailing laws and regulations, as well as to accommodate the expectations of the public to obtain good services from the Government.

\section{Acknowledgements}

This study was supported by The Inspectorate of East Java Province and other related parties (offices, work units, officers, officials, etc.). The author would like to thank to the following people who helped facilitate information, confirmation, and validation until the completion of this study:

1. Inspector/Head of The Inspectorate of East Java Province;

2. Head of The Division of Economy and Development, Inspectorate of East Java Province;

3. Auditors in The Inspectorate of East Java Province and The Audit Board of Indonesia (Agency of East Java);

4. Public Works Office of Highways of East Java Province;

5. The Providers (Contractor and Supervision Consultant) related to the project.

\section{References}

[1] M. M. Alcaraz, A. m. Moctezuma and L. Garcia, "Sustainable Road Maintenance Planning in Developing Countries Based on Pavement Management Systems: Case Study in Baja California, México," sustainability, vol. 12, no. 1, pp. 12-36, 2020.

[2] T. C. Keng and A. R. Hamzah, "Study of Quality Management in Construction Projects," Chinese Business Review, vol. 10, no. 7, pp. 542-552, 2011.

[3] Andriyani, M. Nashir T and N. Angriany, "Karakteristik Campuran Laston Asphalt Concrete Wearing Course," Karajata Engineering, vol. 1, no. 1, pp. 63-72, 2021.

[4] M. T. L. Putra, "Pengaruh Kapur Sebagai Filler Pada Karakteristik Campuran Aspal Beton (AC-WC)," Jurnal Teknik Sipil 2021 Fakultas teknik Universitas Muhammadiyah Jember, pp. $1-8,2021$.

[5] J. Schepers, T. Falk, K. d. Ruyter, A. d. Jong and M. Hammerschmidt, "Principles and Principals: Do Customer Stewardship and Agency Control Compete or Complement When Shaping Frontline Employee Behavior?," Journal of Marketing, vol. 76, pp. 1-20, 2012.

[6] E. Goutama and I. Yudianto, "The Role of Government Internal Control Systems and Utilization of Information Technology in Quality Reports," Journal of Accounting Auditing and Business, vol. 2, no. 1, pp. 47-63, 2019. 
[7] H. Mahmudah and B. R. LS, "Keefektifan Audit Internal Pemerintah Daerah," Jurnal Akuntansi, vol. 20, no. 01, pp. 33-51, 2016.

[8] A. Waluyo, "Skeptisme Profesional Auditor Dalam Mendeteksi Kecurangan," Jurnal Akuntansi Bisnis, vol. Vol. 1, no. No. 1, pp. 18-45, 2008.

[9] Erlina and I. Muda, "Determinants of The Implementation of Risk-Based Internal Auditing in Regencies/Cities in North Sumatera Province," International Journal of Civil Engineering and Technology (IJCIET), vol. 9, no. 5, p. 1360-1372, 2018.

[10] Soehartono, Teknologi Aspal dan Penggunaannya dalam Konstruksi Perkerasan Jalan, Jakarta: Yayasan Badan Penerbit Pekerjaan Umum P.T. Mediatama Saptakarya, 2010. 